\title{
The Impact of Subjective Work Control, Job Strain and Work-Family Conflict on Fertility Intentions: a European Comparison
}

\author{
L'impact sur les intentions de fécondité de la perception \\ subjective de contrôle sur le travail, du stress lié au travail \\ et du conflit travail-famille: une comparaison européenne
}

Katia Begall $\cdot$ Melinda Mills

Received: 27 July 2010/Accepted: 3 June 2011/Published online: 12 October 2011

(C) The Author(s) 2011. This article is published with open access at Springerlink.com

\begin{abstract}
The link between employment and fertility is often only examined by focussing on women's labour market status or the impact of part- versus full-time employment. This study introduces a new explanation by extending research to examine how women's subjective perceptions of control or autonomy over work, job strain and work-family conflict influence fertility intentions. National-level measures of childcare enrolment under the age of three and the occurrence of parttime work are also included to examine their relation to fertility intentions and their interplay with perceptions of work. Using data from 23 countries from the 2004/5 European Social Survey (ESS), multilevel logistic regression models of fertility intentions are estimated separately for women without children and women with one child. Women with higher levels of work control are significantly more likely to intend to have a second child. Higher levels of job strain (time pressure) significantly lower fertility intentions for mothers in contexts where childcare availability is low. The prevalence of part-time work amongst the female work force significantly predicts the intention to become a mother but has different effects for women who work part-time themselves compared with full-time employees.
\end{abstract}

Keywords Fertility intentions - Europe - Employment - Work control · Job strain $\cdot$ Work-family conflict

Résumé La relation entre emploi et fécondité est souvent étudiée en se centrant exclusivement sur le statut de la femme sur le marché du travail et sur l'impact du temps partiel par rapport au temps plein. Cette étude propose une nouvelle approche

\footnotetext{
K. Begall $\cdot$ M. Mills $(\bowtie)$

Department of Sociology/ICS, University of Groningen, Grote Rozenstraat 31,

9712 TG Groningen, The Netherlands

e-mail: M.C.Mills@rug.nl

K. Begall

e-mail: K.H.Begall@rug.nl
} 
en étudiant la façon dont les perceptions subjectives de la femme relatives à son contrôle du travail ou à son autonomie, le stress lié au travail et le conflit travail-famille influencent les intentions de fécondité. Des mesures au niveau national des taux d'accueil d'enfants de moins de trois ans en structure collective et des possibilités de travail à temps partiel sont également prises en compte afin de comprendre à la fois leur impact et leur relation avec les perceptions subjectives du travail salarié et intentions de fécondité. A partir des données de l'Enquête sociale européenne de 2004/5 provenant de 23 pays, des modèles de régression logistique multi-niveaux, avec pour variable dépendante les intentions de fécondité, sont estimés pour les femmes sans enfant et celles avec un enfant. La probabilité de vouloir un deuxième enfant est significativement plus élevée chez les femmes qui ont un plus haut niveau de contrôle sur leur travail. De plus hauts niveaux de stress lié au travail (contraintes de temps) sont associés significativement à des plus faibles intentions de fécondité dans des contextes de faible taux d'accueil des enfants en bas âge. La prévalence du travail à temps partiel parmi les femmes actives est associée significativement à l'intention de devenir mère, mais avec des effets différents selon que les femmes aient elles-mêmes un travail à temps partiel ou à temps plein.

Mots-clés Intentions de fécondité · Europe · Emploi · Contrôle sur le travail . Stress au travail · Conflit travail-famille

\section{Introduction}

The difficulty of combining paid work with family responsibilities has been a prominent focus in fertility research and public policy debates. The massive entry of women into the labour market in the 1960s, and women's gains in educational attainment, is seen as central factors driving fertility postponement (Brewster and Rindfuss 2000). In fact, around $80 \%$ of women between the ages of 25-44 in the European Union are now in paid employment compared to around 50\% 30 years ago (Adema and Whiteford 2007; OECD 2007). This is coupled with recent public debates and policy mandates of the European Commission $(2004,2005,2007)$ to attempt to simultaneously raise both fertility levels and female employment. To strengthen the labour force and increase European productivity, the Lisbon Strategy called for a rise in women's employment (EC 2004). This was coupled with the strategic goal to increase European fertility (EC 2005, 2007). These mandates raise the potential dilemma of how to combine an increase in female employment with an increase in fertility and thus make paid employment more compatible with family responsibilities (Kok 2004; EC 2005; Kohler et al. 2006). It also corresponds to a shift in policy from the male breadwinner/female carer model towards an adult worker model of the family (Lewis et al. 2008).

Although the link between participation in paid employment and fertility has been widely studied, employment is often examined by focusing on women's labour market status or number of hours in terms of part- versus full-time employment (e.g. Brewster and Rindfuss 2000; Rindfuss et al. 2003; Budig 2003; Engelhardt and 
Prskawetz 2004; Vere 2007). Although we have an increasingly adequate picture of the association between labour market participation and number of hours with fertility intentions and outcomes, we lack an understanding of how subjective perceptions of autonomy and control over work, time pressure and levels of workfamily conflict impact fertility decisions.

The central argument of this study is that it is not merely employment versus non-employment that is pivotal, but rather certain job characteristics that enable employment to become more conducive to parenthood. Previous research on work-family conflict has identified various characteristics of 'good' jobs, that allow paid employment to become more compatible with family responsibilities, such as flexibility in timing and organization of work and a higher degree of autonomy (Allen et al. 2000; Perry-Jenkins et al. 2000; Eby et al. 2005; Mills and Täht 2010).

The study provides several contributions to fertility research by introducing the examination of working conditions and subjective perceptions of work in addition to empirical measures of institutional circumstances that might impact fertility intentions across Europe. The first contribution of this study is that it demonstrates the usefulness of women's subjective experiences such as their perceived control or autonomy over work, the impact of job strain and work-family conflict to explain fertility desires.

A second extension of the literature is the acknowledgement and empirical measurement of national contextual factors that might impact fertility intentions. Women's employment and subjective perceptions do not exist in a vacuum, but are shaped by a wider national context where certain policies enhance or constrain the compatibility of paid work and care. In this study, we consider the opportunity to work part-time and the availability of childcare for young children (Castles 2003; Rindfuss et al. 2007; Kravdal and Rindfuss 2008). The ability to combine paid work with parenthood differs considerably across Europe. In the Nordic countries, labour force participation rates are generally high throughout the entire family cycle, whereas in Southern, Eastern and to some extent Western Europe (i.e. the Germanspeaking countries), female and maternal paid employment remain highly dependent on the number of children and the educational attainment of women (Adema and Whiteford 2007; OECD 2007). The aim and scope of national family policies such as parental leave and cash benefits for families are often positioned as the underlying reason for the differences found between countries in female labour force participation and fertility. How far these policies are effective in increasing fertility or labour force participation has, however, been the subject of many studies, most of which yielded ambiguous results (Castles 2003; Gauthier 2007; Hantrais 1997; Neyer 2003; Van der Lippe et al. 2006). This study includes national-level measures of childcare enrolment below the age of three and the proportion of parttime female employment to understand how these macro characteristics are related to fertility intentions and examine their interplay with perceptions of work control and strain on fertility intentions.

Our focus is on fertility intentions, and more specifically, the time-dependent intention to have a first or second child within the next 3 years. Some researchers have argued that fertility intentions are more reliable concerning the total desired 
number of children for aggregate rather than for individual predictions (QuesnelVallée and Morgan 2003) or that the link between intentions and behaviour is weak (Toulemon and Testa 2005). A growing number of studies, however, have demonstrated the high predictive power of fertility intentions. In studies that compare fertility intentions and their subsequent realization, it appears that timedependent fertility intentions, which refer to the intention to have a child within a specified time interval, are good predictors of fertility, even after controlling for background and life-course variables (Schoen et al. 1999; Spéder and Kapitány 2009; Billari et al. 2009; Balbo and Mills 2011). We acknowledge that fertility intentions may be revised because of changing constraints (Spéder and Kapitány 2009), but also maintain that a measure of time-dependent fertility intentions is appropriate to understand fertility decision-making.

We analyse the intention to have a first and second child in separate models, because the intention to become a parent is commonly viewed as a process guided by different considerations than the decision to have an additional child (Hobcraft and Kiernan 1995; Barber 2001). We focus on the intention to have a second child because considering that the total fertility rate is below the replacement level of 2.1 children in most European countries and the widespread two-child norm, we assume that women who intend to make the transition to a third- or higher-order birth are a special and distinct group with different motivations and fertility ideals (Alich 2006; Berinde 1999). Also time-dependent fertility intentions have been found to be the most reliable for individuals with no child or one child (Berrington 2004).

\section{Theoretical Background}

As stated previously, the aim of this study is to introduce new employment-related factors that are associated with the plan to have a(nother) child and test how the effect of these characteristics varies across different institutional contexts. Previous studies relating female employment to fertility have shown that women who work continuously throughout their adult lives have fewer children than women who are not in paid work. In other words, there is a negative relationship between employment and fertility at the individual level. One explanation for this effect is that paid work delays the transition to parenthood mainly by raising the age at first birth (Bernhardt 1993). A competing argument is that the negative impact of paid work on employment only manifests itself after the first child is born. This is because women only become aware of the incompatibility of the mother and worker role when they are confronted with the conflicting demands of childrearing and work and thus delay or forego the birth of a second or third child (Brewster and Rindfuss 2000). In order to theoretically and empirically evaluate the two modes in which employment presumably affects fertility, we formulate separate hypotheses for women with and without children and thus also analyse these groups separately. We first discuss the importance of work characteristics followed by an examination of institutional factors. 
2.1 Subjective Work Control, Job Strain and Work-family Conflict in Relation to Fertility Intentions

Jobs with certain characteristics might be more compatible with family life than others since it is not only the quantity or number of hours, but also the quality of work that matters (Grönlund 2007; Shreffler et al. 2010). Characteristics that have been identified as potentially reducing the conflict between work and family life are control over work, such as flexible working times or arrangements (Van Rijswijk et al. 2004; Byron 2005; Kelly and Moen 2007; Shockley and Allen 2007; Mills and Täht 2010), whilst stressful and irregular jobs tend to increase the conflict experienced between paid work and family (Byron 2005; Grönlund 2007). To understand how these aspects might impact fertility intentions, we draw upon a broader body of literature outside of demographical fertility research on perceived work control, job strain and work-family conflict.

\subsubsection{Subjective Work Control}

The underlying requirements for 'good jobs' that facilitate lower friction between work and family are those with higher autonomy (level of independence given to a worker) and variety (extent to which jobs vary in content, location and routine) (Grzywacz and Butler 2005). Both job autonomy and variety have been frequently linked to higher worker well-being (Hackman and Oldham 1976; Karasek 1979; Kohn and Schooler 1978) and, more recently, to the reduction of work-family conflict (Friedman and Greenhaus 2000; Grimm-Thomas and Perry-Jenkins 1994; Grzywacz and Butler 2005). In general, there appears to be an attenuating effect of autonomy and variety on work-family conflict, and a positive effect on parenting style and other personality features (i.e. self-esteem) (Friedman and Greenhaus 2000; Grimm-Thomas and Perry-Jenkins 1994). Autonomy and variety afford employees the opportunity to learn new things and maintain a feeling of control over their work, thereby enhancing the feeling of responsibility and meaning (Karasek 1979). The ensuing motivation, energy and attitudes derived from work can likewise be mobilized to facilitate functioning in other life domains such as the family (Friedman and Greenhaus 2000) and result in a better 'synergy' between multiple roles (Voydanoff 2004).

Another important employment feature is the level of time flexibility provided by the employer. Flexible work schedules have been shown to have a positive impact on work-family conflict by increasing the time available for family responsibilities and the perception of control (Christensen and Staines 1990; Thomas and Ganster 1995; Han et al. 2010). In a meta-analysis which reviewed 60 studies, Byron (2005) reported that schedule flexibility leads to lower levels of work-family conflict. In a study of the impact of job characteristics on work-family facilitation in the United States, Grzywacz and Butler (2005) found that autonomy and variety were associated with lower reported work-family conflict and higher work-family facilitation. In the Netherlands, Mills and Täht (2010) demonstrated that nonstandard and flexible hours resulted in lower relationship conflict and more time spent with children, particularly for men. In a study conducted in three Finnish 
organizations, Mauno et al. (2006) found that job control (measured as the degree of autonomy in the timing and method of work) protected employees from experiencing high levels of time and strain-based work-family conflict.

Other studies, however, have presented mixed results. In the Netherlands, Van Echtelt et al. (2006) examined the effect of job designs with a high degree of worker autonomy on what they term 'over-employment' and came to the conclusion that this type of job design is particularly time greedy and causes employees to work longer hours than they desire. Autonomy and flexibility are also job characteristics associated with high-status jobs and a high degree of responsibility for organizational outcomes (Schieman and Glavin 2008). High levels of autonomy might therefore also cause the borders between home and work to blur, thereby increasing work-family conflict, especially in high-status jobs. Employees with a high degree of flexibility tend to bring work home more often and have more work-related contacts whilst being at home (Schieman and Glavin 2008).

Since no previous studies have linked work control to fertility intentions, we enter into relatively uncharted theoretical terrain. It is possible, however, to draw upon the previous findings related to work-family conflict to formulate a hypothesis related to fertility intentions. In this study, we subsume several aspects under the broader theoretical construct of work control, which includes autonomy (control over the pace and organization of work, low degree of supervision), variety (variety and challenge at work, or work requires one to learn new things) and time flexibility (employee can decide when to start and finish work). Based on previous research, our first hypothesis is that: higher levels of perceived work control will result in more positive fertility intentions to have both a first and a second child. We assume that women who have jobs that are characterized by a high degree of work control are more able to combine the demands of childrearing and paid work and will also evaluate the possibility of having a second child more positively than women with lower levels of work control.

\subsubsection{Job Strain}

Not only work control, but also the related concept of job strain, has been shown to serve as an important factor for work and family relationships. Job strain may operate via two different mechanisms. The first mechanism emphasizes stress at the workplace. According to this view, job-related strains are reactions or outcomes that result from the experience of stress (Westman 2005). Building on this approach, we would expect to find a direct negative effect of job strain on various outcomes in private as well as working life, including lower fertility intentions.

A second more nuanced mechanism of job strain has been proposed by Karasek (1979), who argues that mental strain is dependent on the job demands placed on the worker in combination with the discretion permitted to the worker in deciding on how to meet these demands. This definition maintains that the decisive factor in subjective experiences of high job demands is the amount of control granted to the worker. Four types of jobs are distinguished in a 'Job Demand-Control' model, which operates according to the combination of demands and control they offer: passive jobs (low demands, low control), low strain jobs (low demands, high 
control), active jobs (high demands, high control) and high strain jobs (high demands, low control). This means that aside from the direct effect of job strain and perceived work control, the combination of high job demands and low perceived work control might result in higher strain. The Job Demand-Control model has been tested on various outcome variables such as well-being, depression, and different aspects of physical health (van der Doef and Maes 1999). Several studies also examined whether the model also holds when work-family conflict is considered (Voydanoff 1988; Duxbury et al. 1994; Thomas and Ganster 1995; Wallace 2005; Grönlund 2007), showing that increased job demands are associated with higher work-family conflict, whilst control has an alleviating effect. In Sweden, for example, Grönlund (2007) found that high job demands increased work-family conflict whereas high job control had the opposite influence. There was, however, no significant interaction between job demands and control, leading the author to conclude that high job demands are associated with higher levels of work-family conflict with the effect of control being rather marginal. Very similar results were obtained in a study of the effect of job control, job demands and social support on work-family conflict and depression in Canadian lawyers (Wallace 2005). Job strain and work control independently influenced work-family conflict, but no multiplicative effects in the form of significant interactions were found. Since the focus of this study is on fertility intentions and not job strain, we do not empirically test the multiplicative model here, but rather assume that the effects of job strain and work control operate independently on fertility intentions.

Previous research has shown that job strain and perceived work control are relevant and important concepts to predict work-family conflict, yet to date, there has been no application of this theoretical model to fertility intentions. Based on these previous explanations and findings, we hypothesize that a high degree of job strain will lead to lower fertility intentions in women who already have one child. We anticipate that women who do not have children will be less influenced by job strain since they have not as of yet experienced the tension between paid work and family responsibilities that children bring (Brewster and Rindfuss 2000).

\subsubsection{Work-family Conflict}

A final interrelated concept regarding work control and job-strain is work-family conflict. Work-family conflict has been defined as 'a form of inter-role conflict in which the role pressures from the work and family domains are mutually incompatible in some respect. That is, participation in the work (family) role is made more difficult by virtue of participation in the family (work) role' (Greenhaus and Beutell 1985, p. 77). Three forms of work-family conflict are generally distinguished: time-, strain- and behaviour-based conflicts.

Time-based conflict is regarded as the most common and occurs when work and family life compete for the individuals' time in such a way that the individual is unable to perform at the preferred levels in both domains. Strain-based conflict arises when stress or tension experienced in one life domain spill over into the other domain. This includes worries about work, which often leads to impatient or irritable behaviour at home (Schulz et al. 2004). Behaviour-based conflict refers to 
the situation where behaviour required in one role makes it difficult to fulfil requirements of another role. One example is the potential role conflict between the stereotypical behaviour of managers like aggressiveness and objectivity. Behaviorbased conflict occurs when the same individual is expected to express emotions in the family such as being warm, and vulnerable (Greenhaus and Beutell 1985; Hammer and Thompson 2003). The different types of work-family conflict often overlap and can be difficult to distinguish empirically. As described in more detail shortly, we use a measure of work-family conflict that refers to both time and strainbased conflict since these are the most relevant for the majority of employees (Greenhaus and Beutell 1985). Our central hypothesis in relation to work-family conflict is that high levels of conflict between work and private life will lead to lower fertility intentions in women who already have one child. Women without children are expected to experience less conflict between their paid work and private life since children put a large claim on parents' time, especially when they are young. We also expect that some women without children will be sensitive to these issues and anticipate that women without children who already place a higher importance on the compatibility of a job with their private lives will be more likely to intend to have a child.

\subsection{Institutional Context}

In addition to employment characteristics and individual subjective perceptions, national level policies operate to enhance or constrain the compatibility of work and care. In this study, we focus on policies designed to maintain or promote the labour force participation of women rather than policies aimed at stay-at-home mothers or the provision of long unpaid leave that might elicit a negative effect on mothers' participation in paid work. Policies that enhance the compatibility between work and care include affordable childcare facilities and the opportunity to work parttime since both reduce the opportunity costs of having children (Gauthier 2007; Walsh 2007).

\subsubsection{Childcare Availability}

Adopting the assumption that a reduction in the opportunity costs of childbearing will result in higher fertility, childcare availability has frequently been hypothesized as having a positive influence on fertility (Becker 1991). The empirical evidence generally shows that a higher availability of childcare has a positive impact on fertility, but there are some mixed findings (Kravdal 1996; Gauthier 2007). Brewster and Rindfuss (2000) found a positive effect of childcare availability on the combination of childrearing and paid employment, showing a higher return to the labour market after childbirth. Others have likewise demonstrated that fertility is positively influenced by reducing childcare costs and increasing childcare availability (e.g. Di Prete et al. 2003; Del Boca 2002). Hank and Kreyenfeld (2003) found that access to informal childcare arrangements significantly increased the transition to first birth in Germany, concluding that availability and not affordability of childcare was central. Rindfuss et al. $(2007,2010)$ also found that increased childcare availability in 
Norway clearly and consistently had a positive effect on fertility. In this study, we focus on childcare for the youngest group of children below 3 years old, which has been demonstrated as a crucial period for the labour market re-entry of women (Castles 2003). We consider it as a close empirical proxy to capture childcare as a policy designed to maintain a mother's continuous labour force participation throughout her childbearing years. In this context, our hypothesis is that a higher availability of childcare for young children will have a positive influence on the intention to have a first and second child for women in paid employment. Furthermore, as an extension of our previous argumentation regarding the importance of work control for fertility decision-making, it is expected that a heightened level of work control is more important in countries with less institutional support in the form of childcare availability. This is attributed to the fact that women in these countries are more dependent on their individual resources if they want to combine childrearing and work. We likewise expect that higher levels of job strain and work-family conflict are associated with lower intentions to have a child particularly in countries where the institutional support of childcare availability is lower.

\subsubsection{Part-Time Work}

Part-time work, usually defined as working less than $30 \mathrm{~h}$ per week, is one of the most widely used work arrangements amongst women of childbearing age to manage work and family responsibilities. In fact, roughly one third of women aged 25-49 employed in Europe work part-time (Van Bastelaer et al. 1997; Margherita et al. 2009). The prevalence of part-time work varies considerably across countries, ranging from over $70 \%$ in the Netherlands, to less than $5 \%$ of women in Bulgaria and Slovakia (Eurostat Statistical Database 2009, Table 3). When part-time work is considered as a way to reduce the incompatibility between work and family life, the assumption is that women work these hours deliberately and voluntarily. This assumption, however, is potentially problematic as one aspect of part-time work is that it is often associated with 'bad' jobs, which are jobs with unfavourable working conditions that offer limited perspectives for advancement (Kalleberg 2000; Blossfeld and Hakim 1997) or have a stigmatizing effect, signalling to the employer that commitment to work is low (Walsh 2007).

Besides being concentrated in certain sectors (i.e. hotel and restaurants, health and education) and lower-paying occupations, there is little empirical evidence that parttime workers in Europe experience their jobs as being worse in quality than a comparable full-time position. A recent examination of working conditions and work-family reconciliation in Europe showed that more than $60 \%$ of women in parttime work cited family responsibilities as a reason to not work full-time, whereas only one fifth indicated that they could not find a full-time job (Margherita et al. 2009). In addition, in terms of work-life balance, mothers in particular report positive effects of reduced working hours (Fagan and Burchell 2002; Van Rijswijk et al. 2004). In addition to controlling for whether women work part- or full-time at the individual level, we also include the opportunity to work part-time in this study as a characteristic of the institutional context. The prevalence of part-time work amongst women in a country is associated with institutional aspects and overall working-time 
regimes, such as the rigidity of the labour market, and thus affects the ability of individuals to opt for reduced hours. In this respect, we hypothesize that a higher prevalence of part-time work amongst women within a country is associated with positive fertility intentions in the case of women who already have one child. This is because these women are more likely to have already experienced time scarcity in full-time employment because of their family responsibilities. Since women who do not have children are expected to be more concerned about establishing themselves in the labour market and building a career, the prevalence of part-time work is not anticipated to influence the intention to have the first child. Furthermore, we also expect an additive effect of work characteristics when the institutional context offers less opportunities to work reduced hours and expect that heightened levels of work control are more important for intending a second child in countries with a lower availability of part-time work. Because women in these countries are expected to experience a stronger time-squeeze when combining paid work and family responsibilities, we also anticipate that higher levels of job strain and work-family conflict are associated with lower intentions to have a second child in countries with a lower availability of part-time work.

\section{Method}

\subsection{Data and Sample}

Data are used from the second wave of the European Social Survey (ESS), a largescale quantitative survey administered in 2004/5 across Europe. We excluded Turkey and Ukraine from the analyses, leaving 23 countries (see Table 3 for a complete list of all countries). ${ }^{1}$ In each country, a representative random probability sample was drawn with strict quality controls employed to ensure that all national samples met the requirements. Each wave of the ESS consists of a core questionnaire on attitudes and values and rotating modules. The 2004/5 wave contained a module on family, paid work and well-being which included information on family life and fertility intentions. The total sample consisted of 49,066 respondents, which was subsequently reduced further to examine fertility intentions as realistically as possible. We also opted to examine women only because of the very different mechanisms involved in paid employment and fertility for women versus men. This meant that the sub-sample used in these analyses included women only who were not older than 45 years at the time of the interview and lived together with their partner or husband. The sample also only included respondents who were engaged in paid labour as a dependent worker $^{2}$ for at least $1 \mathrm{~h}$ in the week before the interview. The final restricted sample used here consists of 1,533 female respondents. For details of the descriptive statistics, refer to Table 2.

\footnotetext{
${ }^{1}$ Turkey is not included because results resemble those from non-Western countries and the related cultural and socio-economic differences. Ukraine had to be excluded because of the lack of reliable macro-level institutional data.

${ }^{2}$ Unfortunately questions concerning job characteristics were not recorded for self-employed respondents.
} 


\subsection{Measures}

The dependent variable is fertility intentions, which was measured by the question of whether the respondent intended to have a(nother) child within the next 3 years, answered on a four-point scale (definitely not, probably not, probably yes, and definitely yes). This variable was subsequently recoded as a dichotomous measure of fertility intentions in which the answers probably not and definitely not were coded as no, and the answers probably yes and definitely yes was coded as yes. In a series of preliminary analyses, we estimated ordered logit models, but since this did not produce considerably different results, we opted for a more straightforward binary measure of intentions.

Explanatory micro-level variables. Perceived work control is measured by an index of six items that asked whether the respondent is allowed to influence the (a) pace of work, (b) daily organization of work, (c) policy decisions, as well as whether the work done (d) requires learning new skills, (e) offers variety and challenge; and, (f) is not closely supervised. These six items were averaged into a scale that ranged from 0.5 to 7.5 with higher values indicating more perceived work control. Internal reliability of the scale is sufficient (Cronbach's $\alpha=0.74$ ). In order to facilitate interpretation, the scale was centred around the mean.

Job strain is measured by the extent to which the respondent feels that there is never enough time to get everything done at work (coded from 1 disagree strongly to 5 agree strongly).

Work-family conflict is measured by a scale that is constructed using four items asking how often the respondents (a) keep worrying about work problems when they are not working, (b) feel too tired after work to enjoy the things they would like to do at home, (c) find that their job prevents them from giving the time they want to their partner or family; and, (d) find that their partner or family gets fed up with the pressures of their job. The four items were averaged into a scale running from 1 to 5 , with higher values indicating more conflict (Cronbach's $\alpha=0.72$ ). Once again, to facilitate interpretation, the scale was centred around its mean. The importance placed on being able to combine family and work when choosing a job (coded from 1 not important at all, to 5 very important) was also included as a continuous measure.

Control variables. The educational attainment of respondents was measured by the total number of years each respondent was enroled in full-time education. Also the number of years the respondent was employed is included to account for individual differences in labour market attachment. To facilitate interpretation, both variables are centred around the grand mean. Furthermore, respondents' age (centred) and, if applicable, the age of the first child is included in the analysis. The number of weekly working hours was also included. As described shortly, models are estimated for women with and without children. In the model for women without children, a cross-level interaction term of the proportion of women working part-time on the country level by a dummy indicating whether the respondent herself works in a part-time job (30 h or less per week) is included. The cut-off point of $30 \mathrm{~h}$ is in line with the definition applied by the OECD in comparative studies (OECD 1999). Furthermore, the educational attainment of the partner is 
included (measured using six categories ranging from $0=$ not completed primary to $6=$ second level tertiary education). Owing to high levels of non-response, it was not possible to include additional information about the partner, such as weekly working hours or access to flexible working times.

Explanatory macro level variables. The availability of child care facilities is measured at the country level, with a variable that indicates the percentage of children of ages 0 to 3 enroled in formal childcare (OECD Family and Education Databases 2000-2005). Opportunities for part-time work are measured by the share of women working part-time (percentage of part-time work amongst the female working population, Eurostat Statistical Database 2009). In order to facilitate interpretation of the coefficients, both variables are divided by 10 and centred around their mean (see Table 3 for macro-indicators per country).

\subsection{Analysis}

A multilevel binary logistic model was run in Stata 10.1 with separate models estimated for women without children and those with one child. The multilevel binary logistic model is a two-level random coefficient model with respondents $(i)$ nested in the country cluster $j$, which includes a random intercept $u_{j}$ for clusters in the latent response model (Rabe-Hesketh et al. 2004; Rabe-Hesketh and Skrondal 2008). The amount of variance attributable to the country level (variance partition coefficient (VPC)) can be calculated as $\sigma_{u 0}^{2} /\left(\sigma_{u 0}^{2}+3.29\right)$ in logistic multilevel models. Although we do acknowledge that the estimates should be interpreted with some caution since this approach of calculating the VPC is influenced by the explanatory variables in the model. In other words, the inclusion of certain level-one variables might increase the estimated VPC compared to the empty model (Snijders and Bosker 1999, Steele 2009). In our analysis, in the empty models, the betweencountry variances in fertility intentions are estimated as $7.3 \%$ and $10.2 \%$ ((women without child and women with one child, respectively). After estimating the full model, the between-country variance in the sample of women without child is fully explained by introducing the contextual variables and the cross-level interactions. In the sample consisting of mothers with one child, the between-country variance in the full model is reduced to roughly $5 \%$.

In order to test whether the effect of the main explanatory variables varies between countries, random slopes for these variables were introduced in the model, but there was no evidence that the relationship between fertility intentions and work characteristics varies across countries. Therefore, the final model only contains a random intercept to account for differences in fertility intentions in the various countries.

\section{Results}

The results of the regression analysis are presented in Table 1. The first finding is that the results are markedly different for women with and without children. This supports previous research, which has also found that issues such as work-family 


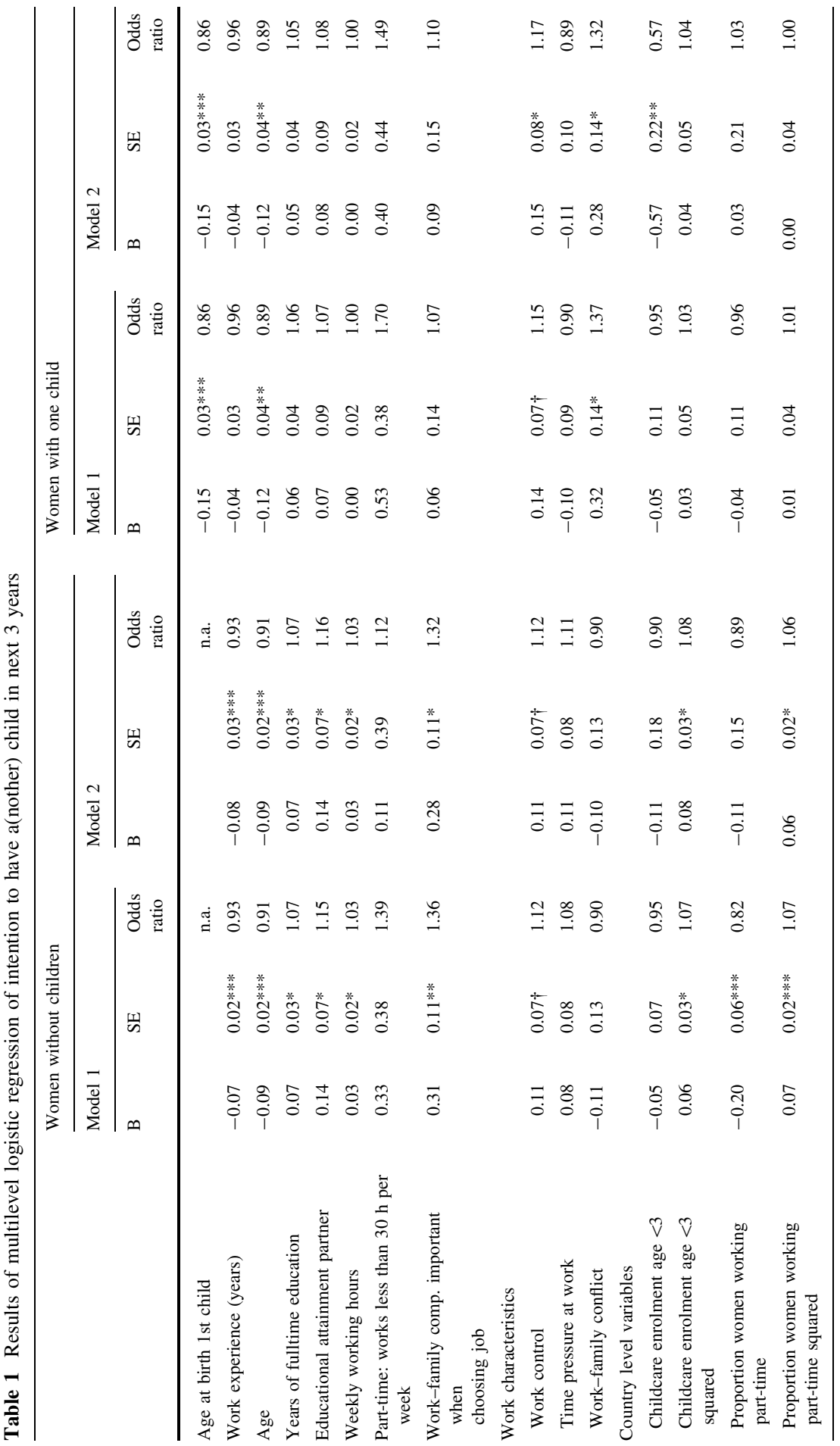




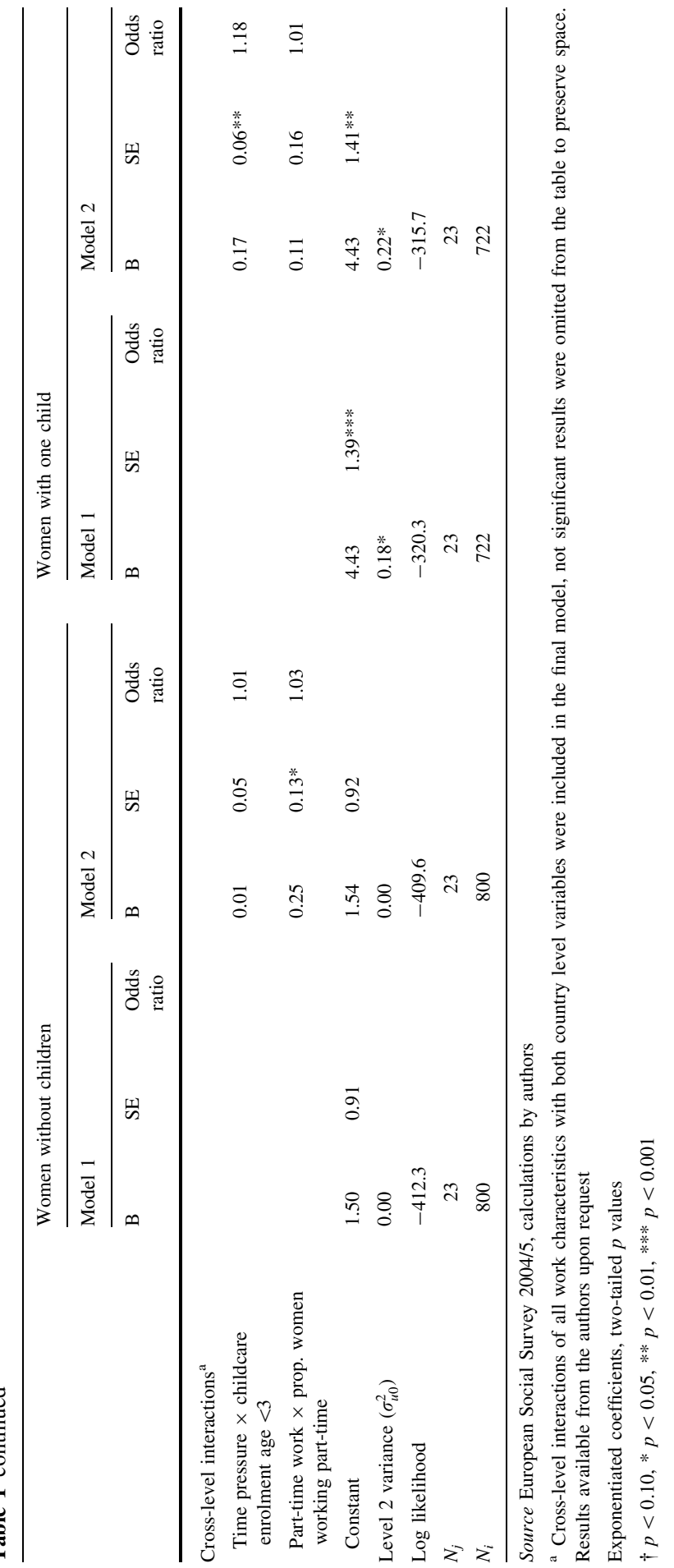




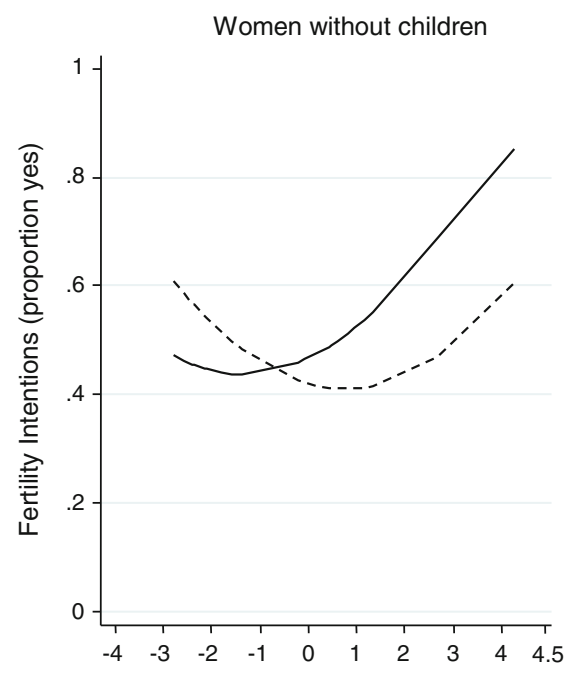

Proportion part-time female employment

$$
\begin{array}{|lr}
\hline \text { Weekly working hours } \\
\hline---- & \leq 30 \text { hours } \\
\hline-30 \text { hours }
\end{array}
$$

Women with one child

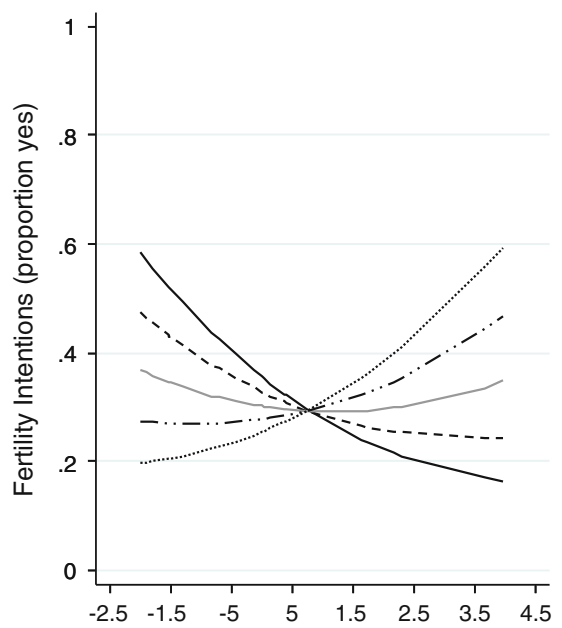

\begin{tabular}{|c|c|c|c|}
\hline \multicolumn{4}{|c|}{ Job strain: Experience of time pressure at work } \\
\hline & Neither agree nor dis & sagree & \\
\hline 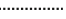 & Agree strongly & $-\cdots->>$ & Agree \\
\hline
\end{tabular}

Proportion children age $<3$ in formal care

Fig. 1 Graphical representation of cross-level interaction effects. Source ESS 2004/2005, calculations by authors. Note: predicted probabilities for $u_{j}=0$

conflict, job strain and control only become salient after the birth of a first child (e.g. Brewster and Rindfuss 2000).

As stated earlier, our first expectation was that a heightened level of perceived work control would positively influence the intention to have a first child (for women without children) and a second child (for those who already had one child). The results support this expectation for women who already had one child. In other words, women who experience higher levels of work control are more likely to intend to have their second child.

We find no support for our second hypothesis, where we anticipated that a high level of job strain would lead to lower fertility intentions for women who already have children. As mentioned earlier, job strain taps the subjective perception that one is unable to get everything done at work, which is a job characteristic that is intrinsically difficult to combine with having another child. One explanation is that these are challenging jobs that offer career perspectives perceived as being incompatible with having additional children. However, as indicated by the significant interaction coefficient between job strain and childcare availability, the direction of the effect of job strain on fertility intentions differs according to the level of childcare availability. To facilitate interpretation of these interaction effects, we have graphed the predicted probabilities in Fig. 1, which were calculated holding the group-level residual at its mean of zero (i.e. substituting $u_{j}=0$, Steele 2009). Turning to the right panel of Fig. 1, we see that women who experience higher levels of job strain (i.e. time pressure at work), are more likely to intend to 
have a second child when childcare availability is high whilst the relationship goes in the opposite direction when childcare availability is low. This is in line with our cross-level interaction hypothesis where we expected that work characteristics would have stronger effects in settings where the institutional context is less supportive. Our results suggest that higher childcare availability is related to higher second birth intentions for women who experience high levels of time pressure at work.

Our third central hypothesis predicted that higher levels of work-family conflict would translate into lower fertility intentions for women who already have children. The results show a strong and positive effect of work-family conflict for mothers with one child, contradicting our expectations. A plausible explanation is that the women who are experiencing the highest levels of work-family conflict are also those placing the highest value on their job and family. Therefore, these women are most likely to stay in paid work, whilst at the same time not compromising their fertility plans.

Turning to the institutional effects, our initial expectation as stated earlier was that the higher availability of childcare would have a positive impact on the intention to have both a first or second child. We do not, find any linear positive effect of childcare, neither for women without children or for mothers of one child. There is however, as described previously, evidence of a diverging effect of higher enrolment in formal childcare on fertility intentions for mothers with one child who experience high levels of job strain (see Fig. 1, right panel). The quadratic term of childcare enrolment is significant and positive in the analysis of women without children, suggesting that the relationship between childcare enrolment and fertility intentions is u-shaped with positive effects at the lower and higher ends of the scale. The reason for the absence of a linear effect might be that the enrolment of children below the age of three in formal care might not sufficiently tap into the availability of care of individual parents, which has been shown to have a positive effect on fertility (Rindfuss et al. 2007, 2010). Nationwide availability, we believe, indicates the general policy climate concerning the compatibility of paid work and childrearing for women. Previous research has shown that particularly in countries in Central and Eastern Europe, characterized by a low availability of formal childcare and high female labour force participation, informal care provided by grandparents and other relatives plays a key role in attenuating conflicts between work and family responsibilities (Bühler and Philipov 2005; Bühler and Fratczak 2007; Sobotka 2002), which can be one explanation for the u-shaped effect found for women without children.

Our final expectation was that a higher prevalence of part-time work amongst women within a country would be associated with positive fertility intentions in the case of women who already have one child. The results do not, however, support this hypothesis. We do find, however, a consistent and negative effect of part-time work on fertility intentions for women without children. To explore this unexpected finding further, we added a quadratic term of this variable into the analysis to see whether the negative effect is linear or u-shaped. The quadratic term proved to be significant which leads us to conclude that women without children in countries with either a very low or very high proportion of women working part-time have 
higher first birth intentions than women from countries with moderate part-time employment possibilities. To explore this effect further, we then added a dummy variable measuring whether the respondent works part-time herself and allowed this variable to interact with the institutional indicator of the proportion of part-time work amongst the female workforce. This interaction was significant and positive, indicating that the relationship between fertility intentions and part-time work on the country level is u-shaped for women who work more than $30 \mathrm{~h}$ per week, but J-shaped for women working part-time themselves (see Fig. 1, left panel). As Fig. 1 illustrates, the two lines intersect slightly below the mean of female part-time work, indicating that women who work full-time (i.e. more than $30 \mathrm{~h}$ per week) have higher fertility intentions compared to those who work part-time in countries where the proportion of female part-time employment is lower than the overall sample average. One explanation for this finding might be the type of jobs where part-time work is located in different institutional settings. In countries where part-time work is less prevalent, part-time jobs tend to be of a lower quality in aspects such as wages. In these contexts, it would be particularly the women without children who might view part-time employment as more of a constraint than an opportunity to combine family and work responsibilities. Conversely, in countries where a large proportion of women are employed in reduced working hours, part-time work is less likely to be related to the quality or level of the job.

Finally, it is interesting to note the varied effects of the control variables that we included in the models for women with and without children. For women without children, higher labour force attachment, indicated by more years in paid employment, is associated with lower fertility intentions whilst women's own education, their partners' education and a higher number of weekly working hours predict the intention to become a mother.

For women with one child, the results show a different pattern of the control variables, with only age and the age of the first child serving as significant predictors of fertility intentions. In order to explore the idea that women without children are less influenced by the characteristics of their present job because they are not yet aware of difficulties that might arise once they have to combine employment with parenting, we introduced a variable in the model to measure the extent to which the respondent thinks that when choosing a job it is important that the job allows them to combine work and family. Placing a higher importance on this hypothetical job characteristic significantly predicts the intention to become a mother but is not associated with the intention to have a second child.

\section{Conclusions}

This study contributes to the existing fertility literature by introducing working conditions, subjective perceptions of work and empirical measures of institutional circumstances to understand fertility intentions across Europe. To theoretically and empirically evaluate the different ways in which employment affects fertility intentions, separate hypotheses for women with and without children were formulated and tested. 
Previous research on perceived work control, job strain and work-family conflict outside of demographical fertility research was used to develop theory and hypotheses about how these factors might influence fertility intentions. Our results show that whilst the 'objective' indicators of labour market position and conditions (labour force experience, working hours, educational attainment of a woman and her partner, prevalence of part-time work, etc.) are strong predictors of the intention to become a mother, the intention to have a second child is more strongly associated with work characteristics. Perceived work control in the form of autonomy and variety in work and time flexibility was previously shown to have a positive effect on reducing work-family conflict. Extending these previous assumptions to fertility intentions, we found support for our expectation that those with higher levels of work control are significantly more likely to intend to have a second child.

Previous research in the domain of work-family conflict has also shown that job strain is an important factor, yet to date, there is a lack of research linking this type of conflict to fertility intentions. The current study found that. for women who already have a child, higher levels of negative job strain (generally time pressure) have an effect on the intention to have a second child only in combination with the availability of formal childcare for young children. We believe that this is because if one already experiences an inability to get everything done at work, the perception appears to be that it would be difficult if not impossible to combine this job with having an additional child when the level of institutional support is low (see also Rindfuss et al. 2010).

Whilst the effect of work control operated in the expected direction, we found an unexpected positive effect of a higher amount work-family conflict on the intention to have a second child. We believe that this effect is attributed to the fact that mothers of one child who remained in paid work but place high importance on family life and on having another child might be more likely to experience higher levels of conflict between paid work and family responsibilities. These women might not want to compromise on family size but still place high importance on participating in the labour force. Unfortunately, we have no measure of labour market attachment in our data that would permit us to test whether this is the case. That the effect of workfamily conflict on fertility intentions is not as straightforward as expected is highlighted by the fact that the only other study, to our knowledge, which used workfamily conflict to predict fertility intentions by Shreffler et al. (2010), failed to find a significant direct effect of the perceived conflict between work and family (measured by a single item) of men and women on the intention to have a child within the next 3 years in a sample of dual-earner couples in the United States.

The results of this study demonstrate clear differences for women with and without children, once again underlining the finding that issues such as work-family conflict, job strain and control only become salient after the birth of a first child, underlined by previous studies (Brewster and Rindfuss 2000). This does of course not mean that women without children are oblivious to these issues, which was demonstrated by the effect of the measure of the importance of work-family compatibility when choosing a job. Placing a higher importance on being able to combine a job with family life strongly predicts the intention to become a parent, indicating that women without children are aware of potential friction between these 
domains of life but relate these potential frictions less to their present job and work characteristics than mothers of one child for whom no effect of this measure was found.

It is plausible that many researchers would argue that a woman's employment career is endogenous with her fertility decisions and ultimate fertility outcomes. This endogeneity can be controlled for statistically by implementing structural equation models or adopting a fixed-effects modelling strategy (see also Rindfuss et al. 2010). It was not possible, however, to overcome this issue within our current study design because only employed women were asked to evaluate their subjective employment perceptions and work characteristics within this cross-sectional data source. It was also not possible to, for example, estimate additional sensitivity analyses that did not include variables related to women's employment to see if results changed. It would be desirable to attempt to tackle these issues in the future either using longitudinal data or by applying the above mentioned techniques.

A strength of this study was to go beyond previous theoretical discussions that underline the importance of institutional factors in shaping fertility, to empirically examine how national level policies in combination with subjective perceptions of paid work can enhance or constrain the compatibility of work and care. We empirically examined how childcare availability for children under 3 years of age and the prevalence of part-time work amongst women within a country impacted the intention to have a second child. We obtained some mixed and very interesting findings in this respect. Contrary to our expectation, only the second-order terms of both institutional indicators predicted the intention to have a first child, whilst no significant main effects were found for mothers of one child. We also found two interesting cross-level interactions indicating that childcare availability is positively associated with fertility intentions for mothers in stressful jobs and that part-time work is only associated with a lower intention to become a mother in contexts where only few other women work part-time.

In conclusion, it appears that to enable women across Europe to fulfil their desires and ambitions in the work as well as the family domain, the institutional as well as the workplace characteristics and the subjective experiences of employment can play a crucial role. The option of staying at home for extended periods of time during the most productive years of life is no longer a viable option for the large majority of European women, neither economically nor in terms of self-actualization and societal participation. Foregoing the birth of children or having a smaller family than preferred, on the other hand, may seem to be a very high price to pay in exchange for employment. Creating and implementing policies that are effective in promoting work-life balance certainly remains a challenge for many policy-makers. It is the hope that this study provides some insights into the more nuanced mechanisms and impact of workplace characteristics and subjective experiences of employment and work-family balance that afford individuals with the ability to fulfil multiple roles in both the workplace and family.

Open Access This article is distributed under the terms of the Creative Commons Attribution Noncommercial License which permits any noncommercial use, distribution, and reproduction in any medium, provided the original author(s) and source are credited. 


\section{Appendix}

Tables 2 and 3.

Table 2 Distributions and descriptive statistics of individual level variables used

\begin{tabular}{|c|c|c|c|c|c|c|c|c|c|c|}
\hline \multirow[t]{2}{*}{ Variable } & \multicolumn{5}{|c|}{ Women without children } & \multicolumn{5}{|c|}{ Women with one child } \\
\hline & $N$ & $\begin{array}{l}\text { Mean/ } \\
\text { prop. } \\
\text { yes }\end{array}$ & SD & Min & $\operatorname{Max}$ & $N$ & $\begin{array}{l}\text { Mean/ } \\
\text { prop. } \\
\text { yes }\end{array}$ & SD & Min & $\operatorname{Max}$ \\
\hline $\begin{array}{l}\text { Intention to have a child } \\
\text { within } 3 \text { years }\end{array}$ & 981 & 0.60 & & 0 & 1.0 & 959 & 0.40 & & 0 & 1.0 \\
\hline Age 1st child & n.a. & n.a. & n.a. & n.a. & n.a. & 947 & 8.29 & 6.43 & - & 27.0 \\
\hline Work experience (years) & 955 & 10.31 & 7.11 & 0 & 31.0 & 958 & 13.78 & 6.89 & 0 & 34.0 \\
\hline Age & 1026 & 31.44 & 6.80 & 19.0 & 45.0 & 1020 & 35.17 & 6.19 & 20.0 & 45.0 \\
\hline $\begin{array}{l}\text { Years of fulltime } \\
\text { education }\end{array}$ & 1023 & 14.03 & 3.30 & 2.0 & 25.0 & 1016 & 13.56 & 3.68 & 2.0 & 30.0 \\
\hline $\begin{array}{l}\text { Educational attainment } \\
\text { partner }\end{array}$ & 1011 & 3.50 & 1.39 & 0.0 & 6.0 & 1013 & 3.33 & 1.36 & 0.0 & 6.0 \\
\hline Weekly working hours & 1002 & 39.04 & 8.63 & 2.0 & 80.0 & 988 & 36.77 & 10.17 & 1.0 & 84.0 \\
\hline $\begin{array}{l}\text { Part-time: works less than } \\
30 \mathrm{~h} \text { per week }\end{array}$ & 1002 & 0.14 & & 0 & 1.0 & 988 & 0.23 & & 0 & 1.0 \\
\hline $\begin{array}{l}\text { Work-family comp. } \\
\text { important when choosing } \\
\text { job }\end{array}$ & 1012 & 4.14 & 0.78 & 1.0 & 5.0 & 1003 & 4.36 & 0.74 & 1.0 & 5.0 \\
\hline Work control & 905 & 4.22 & 1.39 & 0.5 & 7.0 & 874 & 4.05 & 1.59 & 0.5 & 7.4 \\
\hline Time pressure at work & 911 & 3.05 & 1.16 & 1.0 & 5.0 & 882 & 3.13 & 1.15 & 1.0 & 5.0 \\
\hline Work-family conflict & 989 & 2.55 & 0.73 & 1.0 & 4.8 & 989 & 2.59 & 0.78 & 1.0 & 5.0 \\
\hline $\begin{array}{l}\text { Childcare enrolment } \\
\text { age }<3\end{array}$ & 1026 & 22.51 & 15.47 & 2.0 & 61.7 & 1020 & 23.64 & 15.92 & 2.0 & 61.7 \\
\hline $\begin{array}{l}\text { Proportion women } \\
\text { working part-time }\end{array}$ & 1026 & 33.28 & 18.48 & 4.2 & 74.7 & 1020 & 30.02 & 17.33 & 4.2 & 74.7 \\
\hline Valid $N$ & 804 & & & & & 729 & & & & \\
\hline
\end{tabular}

Source European Social Survey 2004/2005

Table 3 Description of macro-indicators of childcare availability and part-time work opportunities

\begin{tabular}{lllll}
\hline & $N$ & $\%$ & $\begin{array}{l}\text { Enrolment in formal } \\
\text { childcare age }<3^{\mathrm{a}}\end{array}$ & $\begin{array}{l}\text { Proportion of female labour } \\
\text { force working part-time }\end{array}$ \\
\hline Austria & 62 & 4.04 & 4.1 & 38 \\
Belgium & 83 & 5.41 & 38.5 & 40.5 \\
Switzerland & 97 & 6.33 & 7.2 & 58.8 \\
Czech Republic & 69 & 4.50 & 3 & 8.3 \\
\hline
\end{tabular}


Table 3 continued

\begin{tabular}{|c|c|c|c|c|}
\hline & $N$ & $\%$ & $\begin{array}{l}\text { Enrolment in formal } \\
\text { childcare age }<3^{\mathrm{a}}\end{array}$ & $\begin{array}{l}\text { Proportion of female labour } \\
\text { force working part-time }\end{array}$ \\
\hline Germany & 109 & 7.11 & 9 & 41.6 \\
\hline Denmark & 72 & 4.70 & 61.7 & 33.8 \\
\hline Estonia $^{\mathrm{b}}$ & 76 & 4.96 & 22 & 10.6 \\
\hline Spain & 62 & 4.04 & 20.7 & 17.9 \\
\hline Finland & 89 & 5.81 & 22.4 & 18.4 \\
\hline France & 78 & 5.09 & 26 & 29.9 \\
\hline Great Britain & 83 & 5.41 & 25.8 & 43.8 \\
\hline Greece & 53 & 3.46 & 7 & 8.5 \\
\hline Hungary & 44 & 2.87 & 6.9 & 6.3 \\
\hline Ireland & 39 & 2.54 & 15 & 31.5 \\
\hline Iceland & 19 & 1.24 & 58.7 & 36.8 \\
\hline Luxembourg & 65 & 4.24 & 14 & 36.3 \\
\hline The Netherlands & 81 & 5.28 & 29.5 & 74.7 \\
\hline Norway & 78 & 5.09 & 43.7 & 45.4 \\
\hline Poland & 44 & 2.87 & 2 & 14 \\
\hline Portugal & 85 & 5.54 & 23.5 & 16.3 \\
\hline Sweden & 85 & 5.54 & 39.5 & 36.3 \\
\hline Slovenia $^{\mathrm{b}}$ & 31 & 2.02 & 45 & 11 \\
\hline Slovakia & 29 & 1.89 & 17.7 & 4.2 \\
\hline Total/mean & 1533 & 100 & 23.1 & 31.2 \\
\hline
\end{tabular}

${ }^{a}$ Source OECD Family and Education databases, data refers to the years 2000-2005

b Source Eurydice database Eurobase

${ }^{c}$ Source Eurostat

\section{References}

Adema, W., \& Whiteford, P. (2007). Babies and bosses: reconciling work and family life: A synthesis of findings for OECD countries. Paris: OECD.

Alich, D. (2006). The third child: a comparison between West Germany and Norway. Rostock, MPIDR Working Paper WP-2006-001.

Allen, T. D., Herst, D. E., Bruck, C. S., \& Sutton, M. (2000). Consequences associated with work-tofamily conflict: A review and agenda for future research. Journal of Occupational Health Psychology, 5(2), 278-308.

Balbo, N. \& Mills, M. (2011). Social capital and pressure in fertility decision-making: Second and third births in France, Germany and Bulgaria. Population Studies. doi:10.1080/00324728.2011.579148.

Barber, J. S. (2001). Ideational influences on the transition to parenthood: Attitudes toward childbearing and competing alternatives. Social Psychology Quarterly, 64(2), 101-127.

Becker, G. (1991). A treatise on the family. Enlarged Edition. Cambridge, MA: Harvard University Press.

Berinde, D. (1999). Pathways to a third child in Sweden. European Journal of Population, 1999(4), 349-378.

Bernhardt, E. M. (1993). Fertility and employment. European Sociological Review, 9(1), $25-42$.

Berrington, A. (2004). Perpetual postponers? Women's, men's and couple's fertility intentions and subsequent fertility behaviour. Population Trends, 117, 9-19.

Billari, F. C., Philipov, D., \& Testa, M. R. (2009). Attitudes, norms and perceived behavioural control: Explaining fertility intentions in Bulgaria. European Journal of Population, 25(4), 439-465. 
Blossfeld, H.-P., \& Hakim, C. (Eds.). (1997). Between equalization and marginalization. Oxford: Oxford University Press.

Brewster, K. L., \& Rindfuss, R. R. (2000). Fertility and women's employment in industrialized nations. Annual Review of Sociology, 26, 271-296.

Budig, M. J. (2003). Are women's employment and fertility histories interdependent? An examination of causal order using event history analysis. Social Science Research, 32(3), 376-401.

Bühler, C., \& Fratczak, E. (2007). Learning from others and receiving support: the impact of personal networks on fertility intentions in Poland. European Societies, 9(3), 359-382.

Bühler, C., \& Philipov, D. (2005). Social capital related to fertility: theoretical foundations and empirical evidence from Bulgaria. In Vienna Yearbook of Population Research (pp. 53-81). Vienna: Austrian Academy of Sciences Press.

Byron, K. (2005). A meta-analytic review of work-family conflict and its antecedents. Journal of Vocational Behavior, 67(2), 169-198.

Castles, F. (2003). The world turned upside down: Below replacement fertility, changing preferences and family-friendly public policy in 21 OECD countries. Journal of European Social Policy, 13(3), 209-227.

Christensen, K. E., \& Staines, G. L. (1990). Flextime: A viable solution to work/family conflict? Journal of Family Issues, 11(4), 455-476.

Del Boca, D. (2002). The effect of child care and part-time opportunities on participation and fertility decisions in Italy. Journal of Population Economics, 15(3), 549-573.

Di Prete, T. A., Morgan, S. P., Engelhardt, H., \& Pacalova, H. (2003). Do cross-national differences in the costs of children generate cross-national differences in fertility rates? Journal Population Research and Policy Review, 22(5/6), 439-477.

Duxbury, L., Higgins, C., \& Lee, C. (1994). Work-family conflict: a comparison by gender, family type, and perceived control. Journal of Family Issues, 15(3), 449-467.

Eby, L. T., Casper, W. J., Lockwood, A., Bordeaux, C., \& Brinley, A. (2005). Work and family research in IO/OB: Content analysis and review of the literature (1980-2002). Journal of Vocational Behavior, 66(1), 124-197.

Engelhardt, H., \& Prskawetz, A. (2004). On the changing correlation between fertility and female employment over space and time. European Journal of Population, 20(1), 35-62.

European Commission. (2004). Employment in Europe 2004: Recent trends and prospects. Luxembourg: Office for Official Publications of the European Communities.

European Commission. (2005). Green paper: Confronting demographic change: A new solidarity between the generations. Brussels: Communication from the Commission.

European Commission. (2007). White paper: Promoting solidarity between the generations. Brussels: Communication from the Commission.

Eurostat Statistical Database. (2009). http://epp.eurostat.ec.europa.eu/portal/page/portal/eurostat/home/.

Fagan, C., \& Burchell, B. (2002). Gender, jobs and working conditions in the European Union. European Foundation for the improvement of living and working conditions. Luxembourg: Office for Official Publications of the European Communities.

Friedman, S. D., \& Greenhaus, J. H. (2000). Work and family-allies or enemies? What happens when business professionals confront life choices. New York: Oxford University Press.

Gauthier, A. (2007). The impact of family policies on fertility in industrialized countries: a review of the literature. Population Research and Policy Review, 26(3), 323-346.

Greenhaus, J. H., \& Beutell, N. J. (1985). Sources of conflict between work and family roles. Academy of Management Review, 10(1), 76-88.

Grimm-Thomas, K., \& Perry-Jenkins, M. (1994). All in a day's work: Job experiences, self esteem, and fathering in working-class families. Family Relations, 43(2), 174-181.

Grönlund, A. (2007). More control, less conflict? Job demand-control, gender and work-family conflict. Gender, Work \& Organization, 14(5), 476-497.

Grzywacz, J. G., \& Butler, A. B. (2005). The impact of job characteristics on work-to-family facilitation: Testing a theory and distinguishing a construct. Journal of Occupational Health Psychology, 10(2), 97-109.

Hackman, J. R., \& Oldham, G. R. (1976). Motivation through the design of work: Test of a theory. Organizational Behavior and Human Performance, 16(2), 250-279.

Hammer, L. \& Thompson, C. (2003). Work-family role conflict: A sloan work and family encyclopaedia entry. Retrieved in April 2010 from the Sloan Work and Family Research Network. http://wfnetwork. bc.edu/encyclopedia_entry.php?id=264\&area=All. 
Han, W.-J., Miller, D. P., \& Waldfogel, J. (2010). Parental work schedules and adolescent risky behaviors. Developmental Psychology, 46(5), 1245-1267.

Hank, K., \& Kreyenfeld, M. (2003). A multilevel analysis of child care and women's fertility decisions in Western Germany. Journal of Marriage and Family, 65(3), 584-596.

Hantrais, L. (1997). Exploring relationships between social policy and changing family forms within the European Union. European Journal of Population/Revue européenne de Démographie, 13(4), 339-379.

Hobcraft, J. \& Kiernan, K. E. (1995). Becoming a parent in Europe. Plenary paper for European Population Conference. In EAPS/IUSSP proceedings of European population conference Milan, September (pp. 27-65).

Kalleberg, A. L. (2000). Nonstandard employment relations: part-time, temporary and contract work. Annual Review of Sociology, 26(1), 341-365.

Karasek, R. A. (1979). Job demands, job decision latitude, and mental strain: Implications for job redesign. Administrative Science Quarterly, 24(2), 285-308.

Kelly, E. L., \& Moen, P. (2007). Rethinking the clockwork of work: Why schedule control may pay off at work and at home. Advances in Developing Human Resources, 9(4), 487-506.

Kohler, H.-P., Billari, F. C., \& Ortega, J. A. (2006). Low fertility in Europe: Causes, implications and policy options. In F. R. Harris (Ed.), The baby bust: Who will do the work? Who will pay the taxes? (pp. 48-109). Lanham: Rowman \& Littlefield Publishers.

Kohn, M. L., \& Schooler, C. (1978). The reciprocal effects of the substantive complexity of work and intellectual flexibility: A longitudinal assessment. American Journal of Sociology, 84(1), 24-52.

Kok, W. (2004). Facing the challenge: The Lisbon strategy for growth and employment/report from the High Level Group chaired by Wim Kok. Luxembourg: Office for Official Publications of the European Communities.

Kravdal, Ø. (1996). How the local supply of day care centers influences fertility in Norway: A parity specific approach. Population Research and Policy Review, 15(3), 201-218.

Kravdal, Ø., \& Rindfuss, R. R. (2008). Changing relationships between education and fertility: A study of women and men born 1940 to 1964. American Sociological Review, 73(5), 854-873.

Lewis, J., Knijn, T., Martin, C., \& Ostner, I. (2008). Patterns of development in work/family reconciliation policies for parents in France, Germany, the Netherlands, and the UK in the 2000s. Social Politics, 15(3), 261-286.

Margherita, A., O’Dorchai, S., \& Bosch, J. (2009). Reconciliation between work, private and family life in the European Union. Luxembourg: Eurostat Statistical books.

Mauno, S., Kinnunen, U., \& Ruokolainen, M. (2006). Exploring work- and organization-based resources as moderators between work-family conflict, well-being, and job attitudes. Work \& Stress, 20(3), 210-233.

Mills, M., \& Täht, K. (2010). Nonstandard work schedules and partnership quality: Quantitative and qualitative findings. Journal of Marriage and Family, 72(4), 860-875.

Neyer, G. R. (2003). Family policies and low fertility in Western Europe. Max Planck Institute for Demographic Research Working Paper 2003-021.

OECD. (1999). Employment outlook. Paris: OECD Publishing.

OECD. (2007). Society at a glance 2006: OECD social indicators. Paris: OECD Publishing.

Perry-Jenkins, M., Repetti, R. L., \& Crouter, A. C. (2000). Work and family in the 1990s. Journal of Marriage and Family, 62(4), 981-998.

Quesnel-Vallée, A., \& Morgan, S. P. (2003). Missing the target? Correspondence of fertility intentions and behavior in the U.S. Population Research and Policy Review, 22(5/6), 497-525.

Rabe-Hesketh, S., \& Skrondal, A. (2008). Multilevel and longitudinal modeling using Stata (2nd ed.). College Station: Stata Press.

Rabe-Hesketh, S., Skrondal, A. \& Pickles, A. (2004). GLLAMM manual. University of California, Berkeley Division of Biostatistics working paper series, paper no. 160.

Rindfuss, R. R., Guilkey, D., Morgan, P. S., \& Kravdal, Ø. (2010). Child-care availability and fertility in Norway. Population and Development Review, 36(4), 725-748.

Rindfuss, R. R., Guilkey, D., Morgan, P. S., Kravdal, Ø., \& Guzzo, K. B. (2007). Child care availability and first-birth timing in Norway. Demography, 44(2), 345-372.

Rindfuss, R. R., Guzzo, K. B., \& Morgan, S. P. (2003). The changing institutional context of low fertility. Population Research and Policy Review, 22(5), 411-438.

Schieman, S., \& Glavin, P. (2008). Trouble at the Border?: Gender, flexibility at work, and the workhome interface. Social Problems, 55(4), 590-611. 
Schoen, R., Astone, N. M., Kim, Y. J., \& Nathanson, C. A. (1999). Do fertility intentions affect fertility behavior? Journal of Marriage and the Family, 61(3), 790-799.

Schulz, M. S., Cowan, P. A., Cowan, C. P., \& Brennan, R. T. (2004). Coming home upset: Gender, marital satisfaction, and the daily spill over of workday experience into couple interactions. Journal of Family Psychology, 18(1), 250-263.

Shockley, K. M., \& Allen, T. D. (2007). When flexibility helps: Another look at the availability of flexible work arrangements and work-family conflict. Journal of Vocational Behavior, 71(3), 479-493.

Shreffler, K. M., Pirretti, A. E., \& Drago, R. (2010). Work-family conflict and fertility intentions: Does gender matter? Journal of Family Economic Issues, 31(2), 228-240.

Snijders, T., \& Bosker, R. (1999). Multilevel analysis: An introduction to basic and advanced modeling. London: Sage Publications.

Sobotka, T. (2002). Ten years of rapid fertility changes in European post-communist countries. Evidence and interpretation. Population Research Centre, University of Groningen, Working Paper Series 02-1.

Spéder, Z., \& Kapitány, B. (2009). How are time-dependent childbearing intentions realized? Realization, postponement, abandonment, bringing forward. European Journal of Population, 25(4), 503-523.

Steele, F. (2009) Module 7: Multilevel Models for Binary Responses: Concepts. LEMMA VLE, University of Bristol, Centre for Multilevel Modelling. Accessed September 2010. URL: http://www. cmm.bris.ac.uk/lemma.

Thomas, L. T., \& Ganster, D. C. (1995). Impact of family-supportive work variables on work-family conflict and strain: A control perspective. Journal of Applied Psychology, 80(1), 6-15.

Toulemon, L., \& Testa, M. R. (2005). Fertility intentions and actual fertility: A complex relationship. Population \& Societies, 415, 1-4.

Van Bastelaer, A., Lemaître, G., \& Marianna, P. (1997). The Definition of Part-Time Work for the Purpose of International Comparisons. Paris: OECD Labour Market and Social Policy Occasional Papers No. 22.

Van der Doef, M., \& Maes, S. (1999). The Job Demand-Control (-Support) Model and psychological well-being: a review of 20 years of empirical research. Work \& Stress, 13(2), 87-114.

Van der Lippe, T., Jager, A., \& Kops, Y. (2006). Combination pressure: The paid work-family balance of men and women in European countries. Acta Sociologica, 49(3), 303-319.

Van Echtelt, P. E., Glebbeek, A. C., \& Lindenberg, S. M. (2006). The new lumpiness of work: explaining the mismatch between actual and preferred working hours. Work. Employment and Society, 20(3), 493-512.

Van Rijswijk, K., Bekker, M. H. J., Rutte, C. G., \& Croon, M. A. (2004). The relationships among parttime work, work-family interference, and well-being. Journal of Occupational Health Psychology, 9(4), 286-295.

Vere, J. P. (2007). "Having it all” no longer: Fertility, female labor supply, and the new life choices of generation X. Demography, 44(4), 821-828.

Voydanoff, P. (1988). Work role characteristics, family structure demands and work-family conflict. Journal of Marriage and the Family, 50(3), 749-762.

Voydanoff, P. (2004). The effects of work demands and resources on work-to-family conflict and facilitation. Journal of Marriage and Family, 66(2), 398-412.

Wallace, J. E. (2005). Job stress, depression and work-to-family conflict: A test of the strain and buffer hypotheses. Relations Industrielles/Industrial Relations, 60(3), 510-539.

Walsh, J. (2007). Experiencing part-time work: Temporal tensions, social relations and the work-family interface. British Journal of Industrial Relations, 45(1), 155-177.

Westman, M. (2005). Crossover of stress and strain between spouses, a Sloan work and family encyclopedia entry. Retrieved in April 2010 from the Sloan Work and Family Research Network. URL: http://wfnetwork.bc.edu/encyclopedia_entry.php?id=1961\&area=academics. 